\title{
Per Year
}

National Cancer Institute

\section{Source}

National Cancer Institute. Per Year. NCI Thesaurus. Code C74924.

A frequency rate of occurrences of something within a period of time equal to three hundred sixty-five days. 